\title{
ANALISIS KIM DALAM MEWUJUDKAN INFORMASI PUBLIK DI DESA SIDOMULYO KECAMATAN ANGGANA KUKAR
}

\author{
Hairunnisa ${ }^{1}$, Muhammad Noor ${ }^{2}$ \\ Jl. K.H Wahid Hasyim 2 Perum. TVRI Graha Asri Blok D No. 109 Samarinda. \\ Email: fokda_2006@yahoo.com
}

\begin{abstract}
Abstrak
Tujuan penelitian untuk mendeskripsikan, dan menganalisis Kelompok Informasi Masyarakat Dalam Mewujudkan Informasi Publik di Desa Sidomulyo Kecamatan Anggana Kabupaten Kutai Kartanegara. Pengambilan data dilakukan dengan metode Snowball Sampling dengan penentuan Key Informan menggunakan metode purposive sampling terhadap responden yang ada di Desa Sidomulyo. Data primer didapat dari wawancara langsung dengan responden yang berdasarkan pada pedoman wawancara, sedangkan data sekunder didapat dari buku. Hasil penelitian menunjukan bahwa dalam penyerapan aspirasi masyarakat dan penyaluran informasi oleh KIM masih sudah berjalan dengan baik Namun, terdapat kelemahan pada sumber daya manusia di internal KIM yang anggotanya sibuk masing - masing dengan profesinya sehingga kinerja KIM kurang maksimal. Kelompok Informasi Masyarakat (KIM) menjadi penampung aspirasi sudah berjalan namun tidak meningkat secara signifikan. Bentuk penerapan dalam penyebaran informasi melalui blog, Website, dan Media Sosial. Hal ini sudah baik hanya memperbaiki komunikasi antara perangkat desa dan Pemeritah Daerah Kutai Kartanegara. Peran Pembina sangat diharapkan oleh KIM Desa Sidomulyo karena untuk fasilitas dan prasana sekiranya sudah dapat dipenuhi oleh perangkat desa.
\end{abstract}

Kata kunci : Partisipasi, Pengetahuan, dan Inovasi.

\begin{abstract}
The purpose of the study was to describe, and to analyze the Community Information Group in Achieving Public Information in Sidomulyo Village, Anggana, Kutai Kartanegara. Data collection was done by Snowball Sampling method by determining Key Informant using purposive sampling method toward respondent in Sidomulyo Village. Primary data obtained from direct interviews with respondents based on interview guidelines, while secondary data obtained from the book. The results showed that in the absorption of community aspirations and information distribution by KIM is still running well However, there are weaknesses in human resources in internal KIM members busy each - each with a profession so that the performance of KIM less than the maximum. The Community Information Group (KIM) to accommodate the aspirations is already running but does not increase significantly. The form of application in the dissemination of information through blogs, Websites, and Social Media. This is good only to improve communication between the village apparatus and the Kutai Kartanegara Regional Government. The role of coach is expected by KIM Sidomulyo Village because for facilities and services if it can be fulfilled by village apparatus.
\end{abstract}

Keywords: Participation, Knowledge, Innovation. 


\section{LATAR BELAKANG}

Dengan pesatnya perkembangan teknologi, mendorong perkembangan teknologi media ikut semakin cepat berkembang juga. Hal ini sebagai tuntutan kehidupan dan kebutuhan masyarakat yang berhubungan dengan tujuan yang hendak dicapai khususnya dalam mengakses kebutuhan akan informasi.

Sebagaimana yang terkandung dalam Permen Kominfo No. 17 Tahun 2009 yang menyatakan Permen Kominfo tetang Diseminasi Informasi Nasional Oleh Pemerintahan, Pemerintah Daerah Provinsi, dan pemerintah daerah Kabupaten/Kota merupakan implementasi dari Peraturan Pemerintah No. 38 Tahun 2007 terkait dengan pengembangan dan pemberdayaan komunikasi.

Kelompok informasi masyarakat di sosialisasikan diskominfo di tahun 2011 yang di landaskan oleh keputusan kementerian komunikasi dan informatika untuk pengembangan dan pemberdayaan lembaga komunikasi sosial yang menjadikan saran komunikasi antara pemerintah daerah dengan masyarakat langsung. Dengan melihat berbagai wilayah di Indonesia khususnya di Kutai Kartanegara, maka diktorat kemitraan komunikasi memiliki peranan strategis untuk melakukan pemberdayaan masyarakat untuk meningkatkan kesadaran atas informasi sebagai suatu sumber pengetahuan dan juga sekaligus meningkatkan kemampuan mengakses informasi dengan mengunakan dan memanfaatkan teknologi komunikasi.

Seperti Desa Sidomulyo merupakan salah satu desa yang berada di Kecamatan Anggana yang termasuk di wilayah di Provinsi Kalimantan Timur, Kutai Kartanegara merupakan pusat perhatian oleh Dinas Komunikasi dan Informatika dikarnakan desa tersebut masyarakatnya memiliki jenjang pendidikan yang rendah. Oleh karna itu di bentuknya KIM di Kecamatan Kembang jangut, Loa janan, dan Anggana, dari 3 kecamatan di tersebut, termasuk desa Sidomulyo di kecamatan Anggana, adalah salah satu daerah yang potensi untuk mewujudkan desa mandiri dari desa yang tertinggal dikarna kan desa tersebut sudah tidak jauh dari tower jaringan dan mobil M-plik dari diskominfo.

Kecamatan Anggana termasuk yang sebagai pusat perhatian oleh Dinas Komunikasi dan Informatika karena desa ini salah satu desa yang membutuhkan komunikasi informasi dikarnakan tidak memliki sumber daya manusia yang mengerti akan informasi dan komunikasi, contoh saja seperti masyarakat di desa sidomulyo yang kebanyakan tidak memiliki jenjang pendidikan yang tinggi oleh karena itu untuk mengakses sebuah informasi, masyarakat tidak tau untuk mengakses informasi dengan mengunakan internet. Sebagai mana di jelaskan seperti di pedoman kementrian komunikasi dan informasi RI , masyarakat harus peka akan arus informasi yang ada dikarnakan informasi adalah salah satu sebuah pesan yang bias membuat kemajuan sebuah lingkungan agar tidak ketinggalan arus informasi dari luar yang menciptakan desa yang mandiri akan mengkases informasi secara sendiri tidak bergantung oleh pemerintah.

\section{KAJIAN PUSTAKA Komunikasi}

Dikemukakan oleh Berlo (1991 : 3 ) dalam The Process of Communication bahwa : "communication is the basic of all human intteraction and this is a social proces". Lebih lanjut, secara rinci dikemukakan oleh Berlo (1991 : 8) bahwa tujuan dan kegunaan komunikasi itu adalah : Pertama informatif yaitu komunikasi itu untuk memberikan informasi, suatu pendekatan pada fikirian. Kedua, persuasif yaitu untuk menggungah perasaan, pendekatan pada fikiran. Kedua, persuasif yaitu untuk menggungah perasaan, pendekatanya lebih pada emosi. Ketiga, entertaimen, komunikasi itu juga untuk menimbulkan rasa senang, rasa nyaman. Dalam proses belajar mengajar, tujuan komunikasi 
itu dijadikan sebuah kelompok dalam mengelolah informasi. Dimana informasi dapat berguna bagi masyarakat sekitar maupun bagi lingkungan pemerintah.

\section{Difusi Inovasi}

Difusi Inovasi adalah teori tentang bagaimana sebuah ide dan teknologi baru tersebar dalam sebuah kebudayaan . Teori ini dipopulerkan oleh Everett Rogers pada tahun 1964 melalui bukunya yang berjudul Diffusion of Innovations. Ia mendefinisikan difusi sebagai proses dimana sebuah inovasi dikomunikasikan melalui berbagai saluran dan jangka waktu tertentu dalam sebuah sistem sosial.

Teori Difusi Inovasi pada dasarnya menjelaskan proses bagaimana suatu inovasi disampaikan (dikomunikasikan) melalui saluran-saluran tertentu sepanjang waktu kepada sekelompok anggota dari sistem sosial. Hal tersebut sejalan dengan pengertian difusi dari Rogers (1961), yaitu "as the process by which an innovation is communicated through certain channels over time among the members of a social system." Lebih jauh dijelaskan bahwa difusi adalah suatu bentuk komunikasi yang bersifat khusus berkaitan dengan penyebaranan pesan-pesan yang berupa gagasan baru, atau dalam istilah Rogers (1961) difusi menyangkut "which is the spread of a new idea from its source of invention or creation to its ultimate users or adopters."

\section{Unsur-Unsur dalam Proses Difusi Inovasi.}

Ada empat unsur pokok dalam proses difusi inovasi yang mempengaruhi adopsi individu terhadap inovasi itu sendiri yaitu :

1. Sifat inovasinya sendiri.

2. Cara dan saluran komunikasi yang dipergunakan.

3. Waktu tertentu yang diperlukan dalam kegiatan difusi inovasi.

4. Karakter individu-individu sebagai anggota sistim sosial yang menjadi sasaran kegiatan difusi inovasi itu.

\section{Waktu Difusi Inovasi}

Unsur waktu dalam proses difusi inovasi meliputi tiga hal, yaitu :

a. Waktu yang diperlukan oleh seseorang untuk mengenal suatu inovasi (awareness) sampai ia menerima (adoption) atau menolak (rejection) inovasi itu.

b. Cepat lambatnya seseorang menerima suatu inovasi juga dipengaruhi oleh kemampuan orang tersebut.

c. Kecepatan adopsi suatu inovasi, ialah kecepatan suatu inovasi diadopsi oleh anggota masyarakat dalam suatu sistim sosial. Kecepatan adopsi ini biasanya diukur dengan waktu yang diperlukan oleh sejumlah persentase penduduk yang telah terlebih dahulu mengadopsi suatu inovasi.

\section{Proses Difusi Inovasi}

Proses adopsi adalah proses yang dialami seseorang mulai ia berkenalan dengan suatu inovasi sampai yang bersangkutan menerima (adopsi) atau menolak inovasi tersebut. Perbedaan antara proses difusi dan proses adopsi ialah bahwa difusi terjadi antar individu sedangkan proses adopsi terjadi di dalam individu itu masing- masing. Proses adopsi merupakan salah satu tipe pengambilan keputusan (decision making). Ada lima tahap dalam proses adopsi, yaitu:
a. Awareness (tahu)
b. Interest (tertarik)
c. Evaluation (penilaian) 
d. Trial (percobaan)

e. Adoption (menerima)

\section{Efektivitas Komunikasi}

Organisasi dapat diartikan sebagai suatu sistem individu yang relatif stabil yang bekerja sama untuk mencapai tujuan bersama melalui struktur hierarki dan pembagian kerja. Tata hubungan di antara anggota organisasi relatif stabil kestabilan susunan organisasi menjadikan organisasi berfungsi secara efektif dalam mencapai tujuannya. Susunan organisasi dapat meramalkan komunikasi di antara anggotanya dan karenanya mempermudah tercapainya tujuan organisasi tersebut (Rogers, 1976: 6).

\section{Kelompok Informasi Masyarakat}

Kelompok Informasi Masyarakat (KIM) merupakan revitalisasi dan reaktualisasi dari kelompok pencari informasi yang disesuaikan dengan paradigma pembangunan dan pemerintah dewasa ini, dengan mengedepankan prinsip demokrasi dan good governance. KIM berperan dalam memperlancar kontribusi dan distribusi informasi kepada masyarakat selain itu menjembatani antara masyarakat dan pemerintah dalam penyebaran informasi dan penyerapan serta penyerapan aspirasi. Masyarakat membentuk kelompok untuk mengatasi persoalan bersama melalui akses dan pemberdayaan informasi.

\section{Tujuan Penelitian}

Berdasarkan latar belakang dan pemersalahan yang telah dikemuka-Kan penelitian ini bertujuan untuk mengetahui Faktor-faktor yang dapat menumbuhkan pertisipasi peserta KIM, Efektivitas komunikasi dalam mempengaruhi perubahan pemahaman, dan aktifitas pada KIM, dan hubungan partisipasi peserta KIM dengan efektivitas komunikasi melalui aktivitas KIM.

\section{METODE PENELITIAN \\ Jenis penelitian}

Metode pendekatan pada penelitian, penelitian penulis digunakan adalah penelitian kualitatif. Yang mendeskripsikan tentang “Analisis Kelompok Informasi Masyarakat (KIM) dalam Mewujudkan Informasi Publik di Desa Sidomulyo Kecamatan Anggana Kutai Kartanegara”. Hal ini dikarenakan, data yang diperoleh tidak dilakukan dengan prosedur statistik, dan data tidak berwujud angka melainkan suatu mutu atau kualitas, prestasi, tingkat dari semua variable penelitian yang biasanya tidak bias dihitung atau diukur secara langsung, dan pendekatan tersebut mengacu pada informasi yang dikemukaan oleh Bungin (2003:302) mengatakan, pendekatan kualitatif memusatkan perhatian pada prinsip-prinsip umum yang mendasari perwujud dan sebuah makna dari gejala gejala sosial di masyarakat.

\section{Jenis Dan Sumber Data}

Sumber data informasi adalah seseorang atau yang dijadikan sebagi narasumber data karena lebih dianggap menguasai bidang permasalahan yang berhubungan erat dengan pelaksanaan sauatu kegiatan. Untuk mempermudah penelitian ini, maka peneliti. Membagi jenis data menjadi 2 (dua) bagian yakni :

1. Data primer

Data primer adalah sumber data yang dikumpulkan peneliti secara langsung dari sumbernya, sumber tersebut diperoleh melalui informan yang berhubungan dengan objek penelitian yakni, Ketua Kelompok Informasi Masyarakat (KIM) Desa Sidomulyo Bapak Saiful Bahari. 


\section{Data Sekunder}

Data sekunder adalah data yang terlebih terdahulu ditelusuri dan dilaporkan oleh orang lain dari luar peneliti. Data sekunder meliputi dokumen-dokumen, arsip-arsip, catatancatatan, gambar terkait dengan penelitian ini.

\section{Teknik Pengumpulan Data}

Teknik pengumpulan data merupakan langkah yang paling strategis dalam penelitian, karena tujuan utama dari penelitian adalah mendapatkan data. Dalam usaha pengumpulan data serta keterangan yang diperlukan dalam penelitian ini adalah penulis menggunakan meted pengumpulan data sebagai berikut:

1. Observasi

2. Wawancara

\section{Teknik Analisis Data}

Teknik analisis data sangat penting dalam suatu penelitian karena di dalam analisis data dilakukan pengorganisasian terhadap data yang terkumpul dilapangan. Sesuai dengan jenis penelitian yaitu deskriptif, maka data akan dianalisis secara kualitatif. Untuk keperluan penelitian tersebut peneliti menyederhanakan data yang diperoleh kedalam bentuk yang mudah untuk dibaca, dipahami dan diinteprtasikan ( Sugiono, 2010:246). Teknik analisis data yang digunakan dalam penelitian ini adalah analisis data kualitatif model interkatif Matthew B.Miles dan A. Michael Huberman yang melalu beberapa tahap yaitu, Pengumpulan Data, Reduksi Data, Penyajian Data, dan Penarikan kesimpulan.

\section{HASIL PENELITIAN \\ Desa Sidomulyo}

Desa Sidomulyo termasuk di dalam wilayah di Kecamatan Anggana Kabupaten Kutai Kartanegara Provinsi Kalimantan Timur. Jarak antara Kabupaten Anggana menuju Desa Sidomulyo sekitar kurang lebih \pm 72 kilometer. Jika ditempuh perjalanan dari Samarinda menuju Desa Sidomulyo melalui jalan darat, menggunakan mobil atau motor dengan kecepatan $60 \mathrm{~km} / \mathrm{jam}$, memakan waktu sekitar \pm 3 jam.

Luas wilayah Desa Sidomulyo yaitu $2000 \pm$ Ha (monografi Desa Sidomulyo tahun 2013) terdiri dari desa, perkebunan, lahan pertanian dan hutan. Penduduknya heterogen terdiri atas banyak suku-suku yang ada di Indonesia. Meskipun demikian, kehidupan suku asli maupun pendatang saling hidup rukun bedampingan dan saling menghormati satu sama lainya. Desa Sidomulyo a sebanyak 16 RT dalam 4 dusun (data diperoleh dari monografi Desa Sidomulyo tahun 2017).

Dari jumlah penduduk tersebut diatas jika dilihat dari segi keagamaan, mayoritas penduduk Desa Sidomulyo adalah muslin. Adapun penduduk Desa Sidomulyo yang lainya memeluk agama Kristen. Meskipun memiliki keanekaragaman dalam hal keyakinan, namun masing masing umat memiliki rasa toleransi yang tinggi tercipta keharmonisan hidup masyarakat dalam perbedaan.

\section{KIM di Desa Sidomulyo}

Kelompok Informasi Masyarakat (KIM) adalah suatu lembaga layanan publik yang di bentuk dan dikelola dari, oleh dan untuk masyarakat sebagai mitra kerja pemerintahan. KIM berorientasi pada informasi dan pemberdayaan sesuai dengan layanan yang dibutuhkannya. Dalam rangka mengembangkan kinerja kelembagaan dibidang pengolahan informasi. Desa Sidomulyo Kecamatan Anggana Kabupaten Kutai Kartanegara Periode 2011-2017 dengan keputusan Kepala Desa membentuk kumpulan atau komunitas KIM. Kelompok Informasi 
Masyarakat (KIM) di dirikan di desa Sidomulyo pada 9 Agustus 2011, KIM di bentuk oleh masyarakat Sidomulyo dan dilaksanakan oleh masyarakat Sidomulyo KIM untuk mewujudkan informasi publik dari desa yang kurang akan informasi dari desa, begitu juga KIM bertujuan untuk meningkatkan nilai taraf hidup masyarakat Sidomulyo melalui mengkases informasi ide baru dalam kehidupan sehari hari.

Sebelum didirakannya kumpulan atau komunitas KIM di Desa Sidomulyo. Untuk mengakses informasi atau mencari informasi yang masyarakat perlukan sangat sulit. setelah adanya KIM masyarakat yang ingin mengetahui atau mengakses informasi lebih mudah. Sebab masyarakat yang mayoritas petani kurang memahami seperti apa internet. Sebelum ada KIM fasilitas untuk mengakses internet sangat sulit terkendala karena tidak adanya tower pemancar jaringan. Untuk potensi desa sendiri awalnya pada bidang pertanian sebelum ada KIM, sayuran seperti seledri sulit untuk dikembangkan. Masyarakat kurang mengetahui seperti apa cara yang tepat untuk menanam dan memanen seldri. Masuknya KIM memberikan perubahan yang signifikan terhadap bidang pertanian. Masyarakat awalnya tidak mengetahui seperti apa bercocok tanam menggunakan sistem hidroponik akhirnya mengerti hal seperti apa yang harus dilakukan. Masyarakat desa Sidomulyo pun berhasil membudidayakan Daun prey sebagai salah satu hasil pertanian selain seledri.

\section{Fasilitator Informasi Bagi Masyarakat}

Kelompok Informasi Masyarakat (KIM), dalam hal ini sebagai fasilitator bagi masyarkat Desa Sidomulyo yang di harapkan mampu menjadi sumber informasi bagi desa sidomulyo sebagai pusat infomasi bagi masyarakat dalam bidang mengakses informasi pembangunan. Untuk mewujudkan hal tersebut, KIM sebagai pencari dan penyebar informasi kepada masyarakat dengan memanfaatkan jaringan internet dan menjadi fasilitas informasi bagi masyarkat, meski hal ini berjalan dengan baik di Desa Sidomulyo. Pelayanan fasilitas oleh KIM untuk Desa Sidomulyo yang belum terlaksana dengan baik yaitu koran desa atau tabloid desa.

Hasil wawancara dengan lima informan menunjukan bahwa dalam penyebaran informasi melalui blog KIM di Desa Sidomulyo, Kecamatan Anggana Kutai Kartanegara telah mulai berjalan. Dihubungkan dengan informasi tentang proses informasi tentang proses komunikasi menurut Harpld D Hasswell (Gamble and Gamble, 1986 :377) yaitu unsur Who (siapa) Say what (pesan apa) in wich channel (saluranya) to whom (penerima) with what effect (efeknya apa) memerlukan perbaikan - perbaikan dari unsur pesan (say what) yang menjadi kebutuhan Desa Sidomulyo. Unsur pesan yang belum memenuhi harapan masyarakat desa Sidomulyo merupakan effect pesan dari penerima secara kelembagaan adanya KIM adalah sesuatu kebutuhan bagi masyarakat desa Sidomulyo. Dalam hal pesan pada Blog KIM sehingga memenuhi keteria yang dikemukakan oleh Rogers and Shalmakees (1971:22-23) yaitu relative advantages (keuntungan relatif) compability (sesuai lingkungan perusahaan) complexity (kerumitan menurut penerima) triability (mudah dicoba) dan (observasibility mudah dilihat hasilnya).

\section{Penyerap Dan Penyalur Aspirasi Masyarakat}

Peran KIM diharapkan menjadi penyerap dan penyalur aspirasi masyarakat di desa Sidomuyo, KIM selalu peka dalam menanggap isu yang berada di desa sidomulyo maupun isu perkembangan desa dan masyarakat sekitar. Aspirasi masyarakat KIM menjadi penampung pendapat dari masyarakat dengan baik dan memecahkan masalah dengan tanggap. Komunikasi sangat dibutuhkan melalui di peran KIM seperti adanya kegiatan rapat atau kumpul untuk memecahakan masalah yang di hadapi. 
Banyak sekalin faktor kendala kendala yang dihapai oleh KIM dalam menjalakan peranya sebagai penampung aspirasi masyarakat, yang sering sekali tidak terlaksana untuk mengadakan rapat bersama yang melibatkan warga desa sidomulyo ini bisa menjadi faktor yang tidak bisa berjalanya dengan baik KIM di desa Sidomulyo. Diharapkan kedepanya bisa menjadi penampung aspirasi masyarakat dan menjalankan peranya dengan baik. Dan kedepanya penasehat bisa menangapi hal ini, dan memberi follow up kepada anggota KIM saat ini dan bisa memberikan solusi bagi KIM Sidomulyo.

Penyerap dan penyalur apresiasi dalam komunikasi berkaitan dengan unsur pada resiver (penerima) dalam hal ini Berlo (1991:72) mengemukakan lima unsur yaitu communication skill, attitude, know leaft, social system dan culture. Hasil wawancara dengan informan menunjukan bahwa dalam penyerap dan penyalur aspirasi KIM masih lemah pada attitude (sikap) yang belum merasa sebagai kebutuhan adanya pertemuan formal maupun non formal. Hal ini dimungkinkan karena unsur culture (budaya) yang di desa Sidomulyo masyarakat heterogen, masih belum membudaya berkelompok yang baik sebagai contoh bekerjasama.

\section{Pelancaran Arus Informasi}

Model arus informasi adalah komunikasi yang berjalan satu arah dari media ke audience, dasar pemikiran KIM menjadi media untuk menyampaikan pesan ke masyarakat. Dasar pemikirannya yang melatar belakangi pelancaran arus komunikasi dari KIM ke masyarakat desa sidomulyo yang harus memiliki sikap pasif terhadap bagai macam informasi yang disebarkan atau disiarkan media massa, sebaliknya media aktif untuk mempengaruhi audience.

kegiatan dalam pengembangan untuk pelancaran arus informasi di desa sidomulyo terhambat dengan kurangnya pembinaan dari pemerintah desa maupun dari pemerintah daerah yang menghambatnya kegiatan KIM dalam berperan sebagaimana mestinya hal ini belum ada tanggapan dari Pemerintah daerah. Pada tahun 2017 memang pemerintah sudah ada mengirimkan seorang pendamping. Namun, ketika KIM sudah mulai aktif, pendamping tersebut di mutasi oleh pemerintah Kukar. Menurut pak Saiful pendamping sangat diperlukan dalam memposting informasi. Karena, sudah adanya undang - undang ITE editor dari KIM berusaha menghindari kata - kata yang sekiranya dapat menyinggung pihak lain.

Berdasarkan observasi yang peneliti lakukan di lapangan, kegiatan sebagai penyalur informasi antar masyarakat di desa sidomulyo sudah aktif. Namun, belum berjalan dengan baik dikarenakan beberapa factor alat dan komunikasi dua arah dari pemerintah daerah ke KIM atau dari pemerintah desa ke KIM.

\section{Terminal Infomasi}

Dalam menyapaikan pesan kepada masyarakat umum, penghubung informasi memiliki opinion leader yang sering sekali untuk bersentuhan dengan informasi dari media yang memiliki kelebihan pengetahuan dalam mengakses data dan informasi agar bisa mengakses informasi dan menyampaikan informasi kepada masyarakat umum yang memiliki tahap tahap dalam menyampaikan sebuah informasi sebagai berikut pesan media sampai ke opinion leader dan tahap kedua pesan opinion leader terhadap masyarakat.

Secara pesan yang disampaikan oleh KIM ke masyarakat yang menjadi sebagai penghubung informasi bagi masyarakat yang secara terus menerus hal ini mencakup dengan tugas KIM yang menyebarluaskan informasi secara akurat dan sesuai apa yang dibutuhkan oleh masyarakat, sehingga KIM harus memiliki opinion leader yang cukup baik untuk bisa tegas dalam menjalankan peran sebagai penghubung informasi dari sebuah informasi ke masyarkat. 
KIM sebagai terminal ke masyarakat desa untuk menyebarluaskan informasi, sangat berpengaruh penting untuk menaikan wawasan desa terpencil. Inputnya informasi sangat menunjang dari sector mana pun, seperti pertanian, informasi berita, dan apa saja yang diperlukan desa berada di informasi, contoh seperti cara cara bercocok tanam yang baik dan benar. Masyarakat juga bisa menggunakan media informasi dengan bijak agar bisa saling belajar hal baru dan tujuan untuk menaikan perekonomian desa tersebut yang memiliki keahlian khusus setelah meliat dan belajar dari apa yang diliat di media online.

Dan ini salah satu kegiatan KIM dalam mengolah informasi, dari menyaring informasi dari media internet dan dipaparkan ke KIM agar informasi di komsumsi bersama, contoh dari informasi yang di olah seperti budidaya daun seledri dan daun prey. Berdasarkan observasi langsung bahwa informasi untuk mencari hal yang baru juga berguna untuk desa terpencil di desa Sidomulyo, dalam bercocok tanam daun seledri, hingga sekarang desa Sidomulyo adalah penghasil daun seledri di Kutai kartanegara.

\section{Kendala-Kendala}

Dalam setiap pekerjaan biasanya terdapak hambatan hambatan maupun kendala yang mungkin dapat menggangu kelancaran pelaksanaan pekerjaan tersebut. Demikian juga dalam pelaksananaan efektivitas kelompok informasi masyarakat (KIM) dalam mewujudkan informasi publik di Desa Sidomulyo Kec. Anggana Kutai Kartanegara.

Dari hasil wawancara tentang kendala KIM yang menjadi faktor penghambat KIM adalah kurangnya pembimbing dari pemerintah Kukar untuk membantu dan mengarahkan KIM di Desa Sidomulyo. Kemudian, para pengurus KIM yang memiliki profesi lain juga menyebabkan kurang aktifnya KIM di Desa Sidomulyo ini.

\section{PEMBAHASAN}

Dalam pembahasan ini peneliti akan mencoba menganalisis bagaimana Kelompok Informasi Masyarakat (KIM) mewujudkan Informasi Publik Di Desa Sidomulyo Kecamatan Anggana Kutai Kartanegara. Peran adalah meliputi norma norma yang dihubungkan dengan posisi atau tempat seseorang atau masyarakat. Dalam arti merupakan rangkaian peraturan peraturan yang membimbing seseorang dalam kehidupan masyarakat.

Efektivitas merupakan dari pengertian sebagaimana membimbing dan sebagai seoarang yang berada disuatu kelompok atau organisasi, yang sifatnya memiliki peran opinion leader yang cukup yang bisa mengerakan anggotanya atau masyarakatnya. Menurut pengertian tersebut, devinisi dari peranan, kegiatan yang dilakukan organisasi untuk mendiskusikan manfaat-manfaat yang diperoleh dari suatu hasil diskusi yang disalurkan kepada masyarakat. Proses peranan dapat dimaknai sebagai membuka pintu gerbang komunitas atau organisasi dan suatu keputusanya diterima dan mendapat sambutan dengan baik dari masyarakat. Hal ini akan menentukan suatu harapan besar bagi masyarakat dengan menjadi sebuah wadah yang bisa menampung aspirasi dari masyarakat dan bisa menjadi kemitraan bagi masyarakat maupun bagi pemerintah daerah.

Efektivitas Kemlompok Informasi Masyarakat (KIM) di desa sidomulyo dalam mewujudkan informasi publik adalah sebuah kelompok yang dibentuk oleh masyarakat dan anggotanya masyarakat, yang merupakan salah satu program dari kementrian komunikasi informasi Indonesia dalam menwujudkan desa desa memahami pentingnya mengakses informasi. Termasuk desa sidomulyo yang memiliki KIM, untuk mewujudkan desa sidomulyo bisa menjadi desa yang mandiri akan mengerti akan informasi dari luar seperti pesan pesan pembangunan maupun pesan pesan pemerintah daerah maupun kota. KIM bertujuan untuk menyebarluaskan informasi di desa untuk menyampaikan sebuah informasi 
yang diperlukan oleh masyarakat desa, melalui dari interaksi sehari hari atau diskusi bersama.

Dari keseluruhan kegiatan KIM dalam mewujudkan informasi publik memiliki aktivitas dalam mengakses informasi, yang melakukan aktivitas untuk mengakses informasi dari berbagai sumber setelah itu melakukan diskusi tentang informasi membahas tetang informasi yang dilakukan oleh anggota KIM setelah dilakukan inforamasi. Dari hal tersebut melakukan penerapan yang merupakan aktivitas untuk menerapkan pengetahuan atau informasi yang telah diperoleh KIM lalu mendiskusikan bersama. Dari hal tersbut KIM bertujuan untuk saling menukar pengalaman dalam mendayagunakan informasi. KIM sebagai penyebaran informasi dalam menyebarluaskan informasi bila informasinya telah diolah dan diyakini sesuai dengan kebutuhan masyarakat sekitar. Dari hal hal aktivitas tersebut KIM juga sebagai menyerap aspirasi masyarakat, yang dapat dilakukan melalui pertemuan antar anggota secara formal maupun informal, dan selanjutnya KIM menjadi saluran inforamsi antara masyarakat sekitar dengan pemerintah desa dan pemerintah daerah.

Dan dari keseluruhan hasil penelitian KIM di Desa Sidomulyo yang meliputi berberapa tugas KIM yang ada, disbanding dulu KIM pada saat sekarang ini sudah berjalan dengan baik walaupun perkembanganya tidak Sigmifikan. KIM di desa Sidomulyo berhasil meningkatkan bidang pertaniannya. Kemudian informasi dari dalam desa juga berhasil diinformasikan melalui blog dan websitanya. Walaupun, pada saat ini blog dan websitenya sudah ditutup KIM menghasilkan terobosan baru dengan menyampaikan informasi seputar Desa Sidomulyo melalui Social Media Facebook. Untuk sarana dan prasarana seperti internet sudah ada di Desa Sidomulyo. Karena sudah adanya Menara jaringan yang sudah dibangun. Bahkan, di Desa Sidomulyo akan dibangun kembali Menara jaringan terbaru. Sedangkan, untuk alat seperti laptop, computer, dan handphone dirasa perangkat desa dapat memenuhi hal tersebut.

Sebagai salah satu program pembangunan nasional, KIM program dari Kementrian Komunikasi dan Informasi yang sangat berguna bagi masyarakat perdesaan dalam upaya mewujudkan manusia Indonesia sejahtera yang mengerti perkembangan arus informasi. Kondisi ini tidak terlepas dari pemberdayaan masyarakat dalam mengelola informasi secara mandiri. Dan dikeluarkannya Peraturan Menteri Komunikasi dan Informatika Republik Indonesia Nomor.17/PER/M.KOMINFO/2010. Tetang Deseminasi Informasi Nasional oleh Pemerintah, Pemerintah Daerah Provinsi dan Pemerintahan Daerah Kabupaten atau Kota. Hal ini dapat menjamin keberlangsungan hidup manusia menjadi tahu betapa pentingnya mengakses informasi di kehidupan sehari hari Desa Sidomulyo tetapi dalam mencapai tujuan tersebut, tentu banyak hambatan yang timbul dalam melaksanakan tugas, fungsi dan peranya, diantaranya seperti kurangnya pembimbing dari pemerintah, fasilitas infrasturktur penunjang kegiatan KIM seperti mesin fotocopy, dan sampai kurangnya Koordinasi dilapangan dan tidak adanya penunjang dana untuk menlakukan aktifitas KIM.

Cara mengatasi hambatan tersebut adalah dengan adanya rapat atau pertemuan informal dan mengadakan evaluasi anggota KIM, dan yang membahas tentang keberlangsungan masalah yang dihadapi oleh KIM di desa Sidomulyo. Mengevaluasi di struktur KIM agar bisa menjadi aktif kembali dan mencari jalan keluar permasalahan yang dihadapin KIM sidomulyo saat ini.

Kepenguruasan KIM desa sidomulyo harus melibatkan keanggotaan yang baru atau melibatkan kaum pemuda pemuda desa, atas hasil rapat bersama kepengurusan dan dari persetujuan penasehat, agar KIM desa Sidomulyo bisa berjalan kembali sebagaimana mestinya.

Pemerintah daerah harus bisa memegang peranan yang penting untuk KIM di Kutai Kartanegara khususnya di Desa Sidomulyo bisa mengontrol setiap bulan agar melihat kinerja 
KIM seberapa jauh berjalan dan berkembang, sehingga KIM merasa diperhatikan oleh pemerintah dan menjadi follow up terhadap KIM Sidomulyo, dan bisa menjadi feedback tanya jawab seputar kekurangan KIM di desa agar tidak terkendala dalam menjalankan tugas-tugasnya.

Pemerintah daerah terutama Pemerintah Desa, agar bisa memperhatikan KIM di desa sidomulyo dan bersikap peka dalam kinerja KIM di desa sidomulyo. Hal tersebut membuat KIM menjadi merasa diperhatiakan oleh pemerintah dengan adanya follow up tersebut, hal ini kemungkinan KIM berjalan sebagaimana mestinya.

1. Faktor faktor yang lebih menumbuhkan partisipasi peserta KIM adalah bila di hubungkan dengan tujuan komunikasi yaitu tidak cukup pada yang memberikan informasi dan mengguggah perasaan kepada masyarakat tetapi yang lebih pada intertaiment. Tumbuh dan berkembangnya partisipasi karena mereka menerima untuk digunakan, dimiliki dan lebih berdaya guna dan berhasil guna. Seperti KIM melibatkan anak dari petani di Desa Sidomulyo untuk menginformasi orang tua nya terkait hal yang diperlukan dalam bidang pertanian

2. Aktivitas KIM di desa Sidomulyo lebih mampu meninggalkan cepatnya perubahan di dalam menerima ide karena pembangunan bagi masyarakatnya dan sekitar akan lebih efektif mana kala unsur pesan (Say what) dalam proses komunikasi lebih di mantapakan dari sumber yang di butuhkan masyarakat sebagai penerima (to when).

\section{SIMPULAN}

1. KIM sebagai jembatan bagi masyarakat desa Sidomulyo berjalan dengan baik karena interaksi antara anggota KIM mengurus KIM di Desa Sidomulyo masih berjalan dibandingkan pada tahun 2016. Pertemuan antara anggota KIM masih berjalan walaupun tidak secara formal. Setelah itu untuk menjalakan perannya sebagai fasilitator informasi bagi masyarakat Desa Sidomulyo KIM ingin mewujudkan Koran Desa tetapi hal ini tidak terealisasikan dikarnakan terhambat oleh faktor penunjang kegiatan KIM seperti kurangnya mesin fotocopy untuk menyesuaikan jumlah dengan masyarakat yang belum memiliki dapat mengakses internet.

2. Komunikasi sangat berpengaruh bagi masyarakat desa Sidomulyo, dan kendala dari hal ini kurangnya pertemuan anggota dan terhadap pemerintah terkait. Pemerintah dahulunya sudah menugaskan pembimbing untuk KIM di Desa Sidomulyo. Kemudian pembimbing tersebut dimutasi dan tidak ada kelanjutan dari pemerintah untuk mungaskan kembali pembimbing KIM di Desa Sidomulyo. KIM masih diperlukan di era teknologi informasi bisa menyampaikan pesan informasi menyeluruh ke daerah terpencil, dalam bentuk informasi pembangunan desa dan memiliki tujuan menciptakan informasi publik.

3. Adanya hubungan yang nyata pada partisipasi KIM di desa Sidomulyo dikarenakan fasilitas penunjang internet memadai, karena mobil E-Mplik, Wifi, dan menara jaringan tersedia di kecamatan, anggota KIM bisa menemukan informasi yang baru, dan mempublish aktivitas desa ke blog dan website KIM Sidomulyo.

\section{REFERENSI}

Ali, M. 2000. Kamus Lengkap Bahasa Indonesia Modern. Pustaka Amami : Jakarta

Ardianto, Elvinaro dan bambang, 2007, Filsafat ilmu komunikasi, Bandung. Simbiosa Rakatama.

Ardianto,Elvinaro dan bambang Qness, 2007, Filsafat ilmu komunikasi, Bandung, Simbiosa Rakatama 
Anonim 1997. The Encylopedia Americana. International Edition. American Corporation. International headquartes : 575 Lexington Avenue, New York 10022

Agung Kurniawan 2005. Transformasi Pelayanan Publik. Yogyakarta: Pembaharuan

Anton M. Meliono, Kamus Besar Bahasa Indonesia, Penerbit Balai Pustaka, Jakarta: 1990

Abdurahmat, $2003 \quad$ Pengertian $\quad$ Efektivitas,(Online), Tersedia http://othenk.com/2008_2008_11_01_achive.html.

Abdul Kadir, Pengenalan Sistem Informasi, Penerbit Andi Yogyakarta, Yogyakarta: 2002

Burgin, Burhan 2003, Metode Penelitian Kualitatif. Jakarta, PT RAJA GRAFINDO PERSADA.

Barelson, Benard and Garry A Stainer. 1979. Communication and Transmission of Information. Cambridge University Press. Massachussetts. Third Edition.

Berlo, David K. 1960. The Process of Communikction. An Introducition To Theory and Practice. Holt, Rinehart and Winston. New York.

Bonner,Neville Thomas Our Resent Past : American Civilization in the Twentieth century. New Jersey : Harper \& Row Publisher.1959

Budi Sutedjo Dharma Oetomo. 2002. Perancangan \& Pengembangan Sistem Informasi, Yogyakarta, Andi.

Barker, Teode L. Doing Social Research 1985. Me Graw Hill Book Company. New York. The Fourth Edition.

Cartwright, D. S. (19971) The Nature of gengs (dalam D.S Cartwright b. Thomsom \& H. Schwarts (red) Gang Deliquency. California : Brooks/cote. Monterey

Cook, Thomas D. 1998, Qualitative an Quantitative Mehods Instrumen Evaluation Reseach sage Publication, Beverly Hills. The Third Edition.

Creswell, Jhon W. 1998 Qualitative Inquiry and Research Design. Sage Publication, Inc. California.

Dahama O.P and O.p Bhatnagar. 1997. Education and Communication For Development Oxford \& IBH Publication Co. New Delhi-bombay-calcutta the fourth Edition

Dilla, Sumadi. 2007. Komunikasi Pembangunan- pendekatan terpadu Edisi Pertama. Bandung; Simbiosa Rekatama Media.

Gamble, Michael W and Teri Kwal Gamble. 1986. Introduction of Mass Communication. McGraw-Hill Vook.co New York. Third Edittion.

Gibson, ID. 1997. Organisasi. Bina Rupa: Jakarta.

Grounlund, Norman E. 1971. Reading In Mesurement and Evaluation. The maemillan Company. Colier-Maemillan Limited. London. The Third Edition.

George H. Bodnar, William S. Hopwood, Sistem Informasi Akuntansi, Buku Satu, Salemba Empat, Jakarta: 2000

Gordon B. Davis, Kerangka Dasar Sistem Informasi Manajemen Bagian_1, PT Pustaka Binamas Pressindo, Jakarta: 1991

Guba, E.G and Y. S. Linclon. 1981. Effective Evaluation. Jossey Bass Publication. San Frasisco. Second Edition.

Handayaningrat, Soewarno (1994). Pengantar Studi Administrasi dan Manajemen. Jakarta : CV.Haji Masagung.

Hamidi. 2004. Metode Penelitian Kualitatid : Aplikasi Praktis Pembuatan Proposal dan Lporan Penelitian. Malang: UMM Pres

Hidayat, A. Aziz Alimul, 1986, Pengantar Kebutuhan Dasar Manusia : Aplikasi Konsep dan Proses Keperawatan Buku 1, Jakarta : Salemba Medika

Jhon F. Cragan dan David W. Wright, Communication ni small Group Discussion, New York: West Publishing Company 1980

Jalaluddin. 1994. Psikologi Komunikasi. Bandung: PRemaja Rosda 
Jogiyanto HM., Analisis dan Disain Informasi: Pendekatan Terstruktur Teori dan Praktek Aplikasi Bisnis, Andi Offset, Yogyakarta: 1999

Kerlinger.Fred N. 1975. Foundation of Behavioral Research. Holt, Rinehart and Wiston. New York. Thrid Edition.

Kurniawan, Agung 2005. Transformasi Pelayanan Publik. Yogyakarta : Pembaharuan.

Papalia, Daiane E and Sally Wendkos Olds. 1985. Psyhology. Mcgraw-Hill Book Company. New York. Tokyo, Toronto.

Rakhmat Jalaludin 1991. Metode Penelitian Komunikasi. Bandung: PT Remaja Rosdakarya.

Rogers, Everett M and F. Floyd Shoemaker 1971. Communication of Innovations. The Free Press. A Division of the Mcmillan Company. New York.

Rogers, Evertt 1960 Diffusion Comunications The Free Press. A Division of the Mcmillan Company. New York.

Rogers, Everett M 1983. Modrenzation Among Peasant, The Impact of communication/

Suhardono, Edy, 1994, Teori Peran Konsep, Derivasi \& Implikasinya, PT. GRAMEDIA Pustaka Utama, Jakarta.

Soekanto, Soerjono, 2002. Sosiologi Suatu Pengantar, Raja Grafindo Persada, Jakarta.

S.P.Siagian, Manajemen, Yogyakarta: Librety.1978

Steers, M Richard. (1985). Efektivitas Organisasi Perusahaan. Jakarta : Erlangga

Salim, P dan Yenny. 1991. Kamus Bahasa Kontenporer. Sinar Grafika : Jakarta

Tangkilisan, Hessel Nogi S. 2005. Manajemen Publik. Jakarta : Gramedia Widia Sarana Indonesia.

Moleong, J, 2002, Metode Penelitian Kualitatif, Remaja Rosdakarya, Bandung.

Mulyana, Deddy, 2008, Metode Penelitian Komunikasi, Bandung, PT Remaja Rosdakarya.

Mcleod, Raymond, 2001, Sistem Informasi Manajemen, Jakarta, PT. Prenhallindo

Newcomb, Theodere M et al 1930, Psikologi Sosial, Bandung. CV. Diponogoro

Neuman (2004 :15) dalam Social Research Method, Qualitative and Quantitative Approach. The Mac Millan Pbulishing, Co. New York. Second Edition.

Little jhon, 2014. Teori Komunikasi ( Theories of human Communication ). Salemba Humanika

Liliweri. Alo. 2011, Komunikasi (serba ada serba makna). Jakarta. Pranada media grup

Lani Sidharta, Pengantar Sistem Informasi Bisnis, P.T. ELEX Media Komputindo, Jakarta: 1995

Lubis, Hari. S.B dan Martani Husaini. 1987. Teori Organisasi (suatu

Yin, Robert K. 2012, Studi kasus dan komunikasi pemasaran, Bandung. PT Remaja Rosdakarya.

Marhaeni Fajar, 2009. Ilmu Komunikasi, Teori dan praktik, Graha Ilmu, Yogyakarta.

Muhammad, Mufid 2004. Komunikasi dan Regulasi Penyiaran. Jakarta : Erlangga

Onong Uchjana Effendy, 2003. Ilmu, Teori Dan Filsafat Komunikasi, PT. Citra Aditya Bakti, Bandung

Osgood, Clack E and P.H Tannebaum. 1977. The Measurement of Meaning. Urbana University of Illinoes Press. The Fourth Edition.

Strauss, Aselm. L 1992. Qualitative Analiysis for Social Scientist. Cambridge University Press and The Publishing Co. New York. The Third Edition.

Sutopo, L. 2002. Teknologi Benih. PT. Raja Grafindo Persada. Jakarta.

Sugiono. 2010 Metode Peneltian Kuantitatif Kualitatif \& RND Bandung : Alfabeta

Tata Sutabri, Sistem Informasi Manajemen, 2005, Yogyakarta.

\section{Referensi Internet :}

https://jurnal.ugm.ac.id/bip/article/view/8290 
(diakses pada 7 Oktober 2016)

$\underline{\text { http://download.portalgaruda.org/article.php?article=368869\&val=7131\&title=PEMBERDA }}$ YAAN\%20KELOMPOK\%20INFORMASI\%20MASYARAKAT\%20(STUDI\%20K ASUS:\%20KECAMATAN\%20TURI\%20DAN\%20KECAMATAN\%20GAMPING, \%20KABUPATEN (diakses 2 Januari 2017)

http://suniscome.50webs.com/data/download/002\%20Desa\%20Mandiri.pdf (diakses pada 9 Agustus 2016)

Wikipedia Ensiklopedia Bebas http://id.wikipedia.org/wiki/Informasi (diakses pada 8 Agustus 2016)

http://ejournal.unisba.ac.id/index.php/mediator/article/view/699/381 (diakses pada 26 Oktober 2016)

\section{Peneliti Terdahulu :}

Maryatun, 2009. Pemberdayaan masyarakat, Kelompok Informasi Masyarakat (KIM) akses informasi, kesejahteraan masyarakat. 2009. UGM, Yogyakarta.

Mudzakir, Agus Ansori, 2008. Tingkat partisipasi anggota kelompok informasi masyarakat (KIM) terhadap pengetahuan dan inovasi dibidang usaha kecil (home industry). 2008 UGM, Yogyakarta.

Johantan Alfando WS, 2013. Peranan Kelompok Informasi Masyarakat (KIM) dalam mewujudkan desa mandiri di desa sidomulyo kecamatan anggana kutai kartanegara. 2013. UNMUL, Samarinda.

Peraturan Menteri Komunikasi Dan Informatika Republik Indonesia Nomor: O8/PER/M.KOMINFO/6/2010 Tentang Pedoman Pengembangan Dan Pemberdayaan Lembaga Komunikasi Sosial

Badan Perencanaan Pembangunan Nasioanal Dan Departemen Dalam Negri, Panduan Program Inpres Desa Tertinggal, Jakarta, Maret 1994 